\title{
Countermeasure Analysis to Problems in China’s Seaman Market
}

\author{
Nie Xiujun, Qinghui Yuan, Haijun Yang, Xiuyan Zhang \\ Ocean Department of Binzhou Polytechnic, Binzhou, China \\ jshnie16@163.com
}

Keywords: seaman market, industry organization, school-government cooperation, countermeasure analysis

\begin{abstract}
China's seaman market has started to go into a downturn, the aging, temporary shortage, and decline of qualities of seamen are an obvious trend, exerting a negative impact on the economic development. Therefore, given such problems, the Chinese government shall actively strengthen school-government cooperation supported by industry organizations so as to cultivate qualified seaman teams for China.

Since the shipping economic crisis of 2008, the shipping market has long been a depression, so has the seaman market. According to the statistics of Maritime Education Research, the number of licenses of third mates and third engineers has reduced by almost $30 \%$ by the end of 2016 , a considerable proportion of seamen with junior certificates has left for other fields. Since 2010, the enrollment of maritime universities and colleges has dropped sharply, and the quality of students has also declined. For the current depression in the seaman market, it is necessary to analyze the causes and find the measures.
\end{abstract}

\section{The current seaman market in China}

\subsection{Temporary shortage of seaman team}

According to the statistics of Development Planning for Chinese Seaman (2016-2020), there are 1.38 million sailors in China, among which 640,000 are seamen. Theoretically, they can meet the needs of shipping market in China. However, many seamen do not serve in the front line, such as managers in the shipping companies, professional teachers and managers in maritime universities and colleges. As a large number of seamen with licenses have long left the front line, the shortage of seamen is prominent in the market. The sailors do not have enough successors, and marine graduates find jobs from ship-owner market to the sailor market. The main reasons are as below: First, the wages of seamen in operation decrease year by year, the income gap between those on board and off board is narrowing. Second, the working conditions of seamen are harsh and closed, with high occupational risks. Third, as the increase of tonnage of ships, ships do not increase, especially, ocean vessels rather, reduce. In addition, the depression in the shipping market has a negative impact on the employment of sailors. Therefore, the attraction of the occupation of seamen decreases, and the practitioners reduce accordingly.

\subsection{Obvious aging of seamen}

According to the 2017 sixth regular press conference held by the Ministry of Transport of China, with the decrease of demographic dividend, the seaman teams are aging. Table 1 and table 2 show the age distribution of seamen with international and coastal navigation licenses.

It can be seen from tale 1 and 2 that, 40-odd seamen holding international endorsement attesting the recognition of certificate of competency account for $27 \%$ of the total, while 40 -odd seamen with coastal navigation certificate of competency account for $62 \%$ of the total, showing an aging tendency. 
Table 1 Age distribution of seamen with international endorsement attesting the recognition of certificate of competency

\begin{tabular}{|c|c|c|c|c|c|c|c|}
\hline post & $\begin{array}{c}18 \leqslant- \\
<20 \\
\end{array}$ & $\begin{array}{c}20 \leqslant- \\
<30 \\
\end{array}$ & $\begin{array}{c}30 \leqslant- \\
<40\end{array}$ & $\begin{array}{c}40 \leqslant- \\
<50 \\
\end{array}$ & $\begin{array}{c}50 \leqslant- \\
<60 \\
\end{array}$ & $\geqslant 60$ & total \\
\hline captain & 0 & 0 & 3147 & 9035 & 2941 & 561 & 15684 \\
\hline $\begin{array}{l}\text { First } \\
\text { mate }\end{array}$ & 0 & 278 & 7469 & 1619 & 445 & 83 & 9894 \\
\hline $\begin{array}{l}\text { Second } \\
\text { mate }\end{array}$ & 0 & 4098 & 8792 & 1071 & 394 & 24 & 14379 \\
\hline $\begin{array}{l}\text { Third } \\
\text { mate }\end{array}$ & 0 & 17464 & 4247 & 362 & 15 & 0 & 22088 \\
\hline $\begin{array}{l}\text { Chief } \\
\text { engineer }\end{array}$ & 0 & 1 & 2644 & 8782 & 3023 & 528 & 14978 \\
\hline $\begin{array}{l}\text { First } \\
\text { engineer }\end{array}$ & 0 & 241 & 6044 & 1468 & 410 & 117 & 8280 \\
\hline $\begin{array}{l}\text { Second } \\
\text { engineer }\end{array}$ & 0 & 3770 & 8080 & 1226 & 402 & 30 & 13508 \\
\hline $\begin{array}{c}\text { Third } \\
\text { engineer }\end{array}$ & 0 & 14122 & 3095 & 325 & 16 & 0 & 17558 \\
\hline $\begin{array}{c}\text { Sailor on } \\
\text { duty }\end{array}$ & 30 & 40017 & 24471 & 13712 & 7159 & 604 & 85993 \\
\hline $\begin{array}{l}\text { Motorman } \\
\text { on duty }\end{array}$ & 13 & 28332 & 16902 & 10801 & 4507 & 409 & 60964 \\
\hline total & 43 & 108323 & 84892 & 48409 & 19303 & 2356 & 263326 \\
\hline
\end{tabular}

Table 2 Age distribution of seamen with coastal navigation certificate of competency

\begin{tabular}{cccccccc}
\hline post & $\begin{array}{c}18 \leqslant- \\
<20\end{array}$ & $\begin{array}{c}20 \leqslant- \\
<30\end{array}$ & $\begin{array}{c}30 \leqslant- \\
<40\end{array}$ & $\begin{array}{c}40 \leqslant- \\
<50\end{array}$ & $\begin{array}{c}50 \leqslant- \\
<60\end{array}$ & $\geqslant 60$ & total \\
\hline $\begin{array}{c}\text { captain } \\
\text { First } \\
\text { mate }\end{array}$ & 0 & 10 & 1787 & 5991 & 6188 & 2629 & 16605 \\
$\begin{array}{c}\text { Second } \\
\text { mate }\end{array}$ & 0 & 1347 & 3498 & 2432 & 2000 & 345 & 9622 \\
$\quad \begin{array}{c}\text { Third } \\
\text { mate }\end{array}$ & 0 & 1177 & 772 & 308 & 90 & 18 & 2365 \\
$\quad \begin{array}{c}\text { Chief } \\
\text { engineer }\end{array}$ & 0 & 1 & 1293 & 6164 & 5954 & 1738 & 15150 \\
$\begin{array}{c}\text { First } \\
\text { engineer } \\
\quad \begin{array}{c}\text { Second } \\
\text { engineer }\end{array}\end{array}$ & 0 & 168 & 2517 & 3388 & 2081 & 356 & 8510 \\
$\begin{array}{c}\text { Third } \\
\text { engineer }\end{array}$ & 0 & 1653 & 858 & 305 & 63 & 8 & 2887 \\
$\begin{array}{c}\text { Sailor } \\
\text { on duty }\end{array}$ & 39 & 6264 & 8121 & 8275 & 9051 & 2166 & 33916 \\
$\begin{array}{c}\text { Motorman } \\
\text { on duty } \\
\text { total }\end{array}$ & 9 & 5135 & 6157 & 5429 & 4142 & 625 & 21497 \\
\hline
\end{tabular}

\subsection{Dramatic decline of seaman quality}

The occupation characteristics of seaman require expertise, independent working abilities, team spirit, as well as the spirit of arduous struggle. However, currently, marine students are mostly the 
only child in the family, in which they rely heavily with less consciousness of independence and team. Besides, their cultural knowledge is poor. Undergraduates just pass the minimum score of the college entrance examination, and the scores of most junior college students are less than 300, among which a large number are admitted to the universities by independent enrollment rather than the college entrance examination. For those students, they have shown poor learning abilities, slow speed in receiving cultural knowledge and professional knowledge with poor or zero English foundation.

Third, those students cannot bear hardships, and many of them leave this job due to the harsh circumstances of shipping work.

\section{Countermeasures for the current seaman market in China}

The education provided by China for seamen is relatively low, and youngers choosing seaman as their post are less and less. National mariner management companies particularly those in the South have brought in mariners from Vietnam, Myanmar, and Kingdom of Cambodia.

China is a large country with 1.4 billion populations where regional economic development is uneven between the central and western parts, and the income gap is rather large. While the post of seaman has significant economic and social benefits. By assigning seamen abroad can not only earn foreign exchange but ease the employment pressure of seaman domestically, making a contribution to the moderately prosperous society. Since $80 \%$ of cargoes are transported by ships, and China' economy is rapidly growing, it is inevitable to have a seaman team. Therefore, the share of seaman market should be enlarged and strengthened instead of giving it to the foreigners.

At the same time, it should be noted that, seaman teams face a good opportunity for development. in 2016, the development of seaman team was included into the 13th Five-Year Plan of integrated transport service by the Ministry of Transport. As the development planning of China's mariners (2016-2020) indicates issued by the Ministry of Transport, China will realize the goal of a marine power by the end of 2020. Thus, it is important to strike a balance between the government, industry and school-government cooperation, (figure 1) in order to improve the environment of seamen in China radically, and the following is the suggestion.

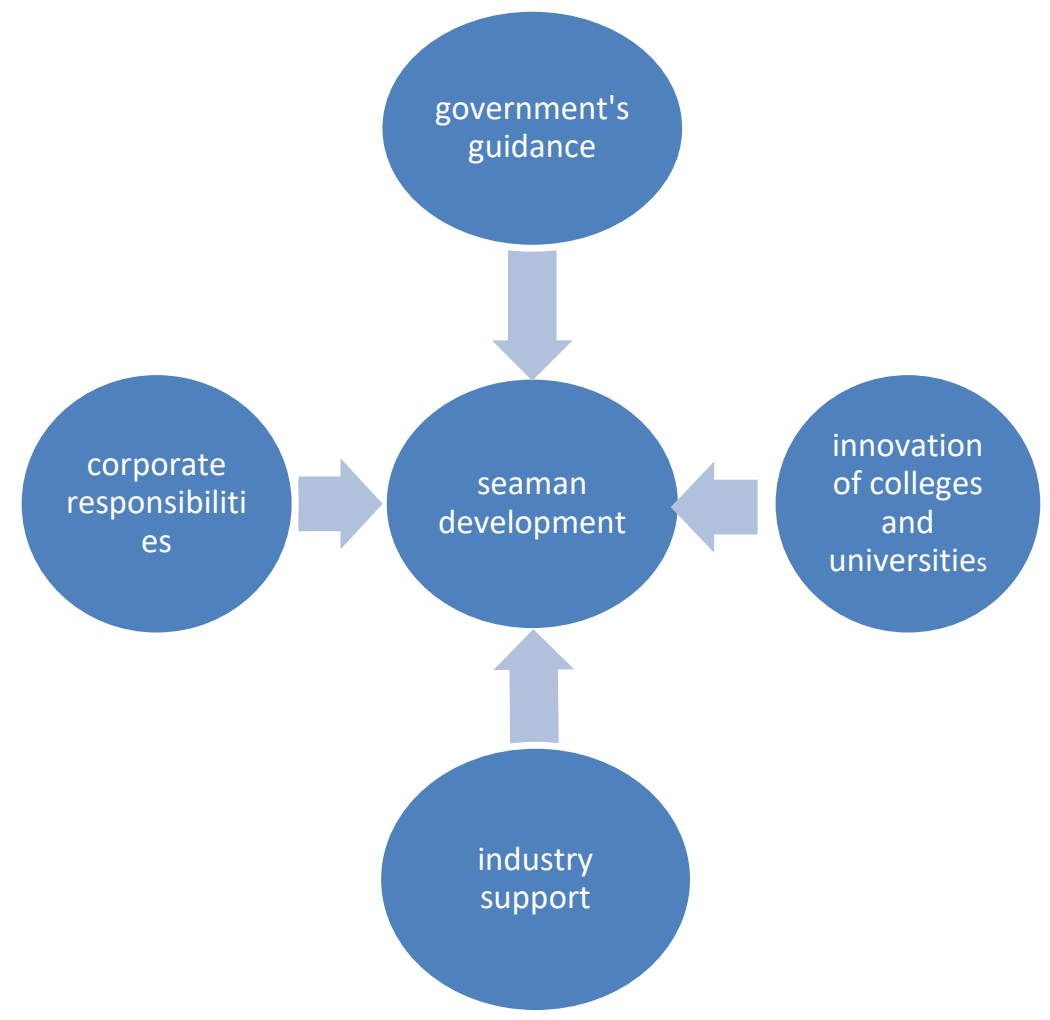

Figure 1 The composite force to cultivate high-quality seamen 


\subsection{Accelerate top-level design}

The development of seaman market is closely associated with the support and coordination of the government, maritime safety administration in the Ministry of Transport is the competent department if seaman management, but an administrative body for promoting economic development, protecting rights and interests of seamen, and safeguarding maritime sovereignty. The maritime safety administration, hence, shoulders the responsibilities and obligation to drive the prosperity and development of seaman market.

First, the maritime safety administration shall cooperate with other administrations to introduce incentive policies so as to arouse shipping companies' enthusiasm such as tax reduction policy, tax exemption for wages of seamen. And the competency examination should be changed to transform the focus of seaman training from process control to the management by objectives.

Second, the maritime safety administration shall strengthen the promotion and publicity of the shipping culture. As the soul of a nation should be subtly influenced by the culture, the profound culture is a strong driver and the spiritual guarantee of the sustainable economic development, which would impact the social identity as well as social status of seamen.

Third, improve the fund investment mechanism. It is important to improve the investment system of seamen education by government, enterprises and nongovernment sectors. The investment should not just flow into the Dalian Maritime University, but also into the seaman training institutions throughout the country, like free tuition for seamen, scholarship for all seamen, so as to encourage needy students to become seamen.

Forth, the maritime safety administration should lead enterprises, schools and industrial organizations to enroll students in middle and western regions. For instance, it can increase the educational resources with Ministry of Education in the concentrated contiguous areas in middle and western regions to provide opportunities for them to accept education in the maritime universities.

The maritime safety administration shall help targeted poverty alleviation with the Ministry of Education to implement the East-West coordination action plan in vocational education (2016-2020), conduct joint enrollment and cooperative education in secondary vocational schools, strengthen the cooperation and collaboration in seaman vocational education. In this process, the enterprises shall expand investment to help solve the problems of tuition and living expenses of students in poor areas of western China.

\subsection{Improve the enthusiasm of industrial associations}

Shandong seafarer service association is a community organization registered in the civil administration department, serving as a bridge between the maritime safety administration and the shipping companies. The work of the association promotes the sound development of seamen market by coordinating the cooperation and interest sharing between shipping companies and related training institutions

Tripartite coordination mechanism of Labor relation in Shandong Province fulfills the Maritime Labor Convention, 2006, plays a part in improving work conditions and life of seamen, making seamen work decently, protecting legitimate rights and interests and motivating the working enthusiasm of seamen.

Shandong Seaman Worker's Union proposed the concept of "protecting rights of workers, driving reform and development" to further promote the seaman development in Shandong Province by seizing the opportunities in the shift of drivers.

And Shandong Seafarer Service Association takes the seaman development in Shandong as its mission, protects rights and interest of seamen, concerns seaman development, cracks down on illegal intermediaries in cooperation with Shandong Seaman Worker's Union and tripartite coordination mechanism of Labor relation in Shandong Province, making contribution to the prosperity and innovative development of national economy. 


\subsection{Promote the joint development of schools and the government}

Maritime universities, colleges and shipping companies are the main places for seaman training and education, advertising vehicles for the vocation of seamen as well as the constructors of the seaman market, which greatly promote the maritime development in China. Currently, the development of seaman market has been included into the 13th Five-year Plan of integrated transport service by the Ministry of Transport. And improvement of training mechanism for shipping talents, enhancement of the qualities of seamen, especially of the senior seamen, as well as the attraction of this occupation have become the bounden duties for schools and enterprises. Therefore, schools and enterprises shall cooperate, mutually exchange, keep striving to realize the dream of a seaman power of China.

First, arouse the active consciousness of enterprises. The structural supply-side reform in China's maritime industry has promoted the merging and reorganization of maritime enterprises. After merging, the shortage of quality and ordinary seamen in maritime enterprises is prominent, so it is time for enterprises to intensify measures, recruit competent seafarers by student grants and living subsidies.

Second, strengthen the faculty construction. Teachers play a leading role in the education, whose quality has a direct effect on the quality of students. The colleges, thus, should strengthen the training of teachers with double qualities both in theoretical teaching and teaching practice, promote the communication between workers and faculty and students to form a system, further enhancing training methods, increasing practical operation, and enhancing the training qualities.

Third, improve enrollment management methods. Under the guidance of enrollment policy of Ministry of Education, the school-enterprise joint enrollment strategy will be implemented led by maritime safety administration with the support of the industry, and the scope of enrollment of secondary vocational schools and high school graduates in more middle and western regions should be expanded. The cooperation mechanism between the eastern maritime colleges and western secondary vocational schools shall be established to link secondary and higher vocational education, undergraduate and postgraduate education in an orderly manner. The number of enrollment increases driven by a set of policies, improving the quality of enrollment.

Fourth, reform the talent training pattern. The seaman training mainly adopts the examination of maritime safety administration first, and then, work as an intern on board, which fails to assess the capabilities of solving problems and learning of students, as well as the internship on board. Therefore, the present seaman training mode should be changed to a new one mimicking the sandwich, that is, students obtain the certificate of sailor or engineer, then, work on probation for over 6 months, study in the school and accept the assessment. This method makes enterprises take part in the cultivation of seamen, achieving the connection between school training and the industrial needs.

Fifth, cooperation between schools and government to create a curriculum system. Give the differences in seaman's practical operation and comprehensive qualities in different seaman market, a multi-level seamen training system is built. And multi-level maritime companies should be encouraged to work with educational and training institutions according to various needs, conduct customized and modular training. Based on the training outline of the maritime safety administration and the requirements for model course by IMO, courses are improved to keep pace with time and shape a curriculum system meeting needs of different seaman markets.

\section{Conclusion}

In a word, Chinese seamen are major performers of the great idea of "Maritime Power" and "Maritime Silk Road". Therefore, in order to promote the development of seaman market, it is necessary to shoulder responsibilities, deepen reform and innovation, learn the spirit in the 19th session of national congress of the communist party of China guided by the socialist ideology with Chinese characteristics in the new era under the leadership of Xi Jinping, remain true to the original aspiration and keep the mission firmly in mind, and build a sound seaman market system in China. 


\section{Acknowledgements}

Construction of multi-culture system for seafarers in different markets

\section{References}

[1] Sun Peiting, Yao Wenbing. Countermeasures for the environmental change and development of Marine education in China [J]. Marine education research, 2013(1):1-6.

[2] Information Office of the Ministry of Transport. China's crew development report 2015 [M]. Dalian: Dalian maritime university press, 2016:8-9.

[3] Duan Zunlei. A study on the career development of Chinese seafarers [J]. Research on navigation education,2017(1):9-14.

[4] Yao Wenbing, Wang Qingming, Qiang Jianzhong. Survey report on employment choice and career status of Marine majors [J]. Sailing education research, 2017(1):1-8.

[5] Zhao Jian, Zhao Lu, Wang Xinjian. Comparative analysis and reference of Chinese and foreign maritime education models [J]. Research on Marine education,2017(1):41-45. 